\begin{tabular}{|c|l|}
\hline Title & Establishment and Characterization of Seven Continuous Cell Lines from Freshwater Fish \\
\hline Author(s) & Fernandez, R. D.; Y oshimizu, M.; Kimura, T.; Ezura, Y. \\
\hline Citation & $\begin{array}{l}\text { Journal of A quatic A nimal Health, 5(2), 137-147 } \\
\text { https://doi.org/10.1577/1548 8667(1993)005<0137:EA COSC >2.3.C0;2 }\end{array}$ \\
\hline Issue Date & 1993-06 \\
\hline Doc URL & http://hdl.handle.net/2115/38311 \\
\hline Type & article \\
\hline File Information & yoshimizu-118.pdf \\
\hline
\end{tabular}

Instructions for use 


\title{
Establishment and Characterization of Seven Continuous Cell Lines from Freshwater Fish
}

\author{
R. D. Fernandez, M. Yoshimizu, T. Kimura, and Y. Ezura \\ Laboratory of Microbiology, Faculty of Fisheries \\ Hokkaido University, Hakodate 041, Japan
}

\begin{abstract}
Seven continuous cell lines were established from salmonid and nonsalmonid fishes. Salmonid cell lines derived from rainbow trout Oncorhynchus mykiss and chum salmon $O$. keta were designated RTE and RTE-2 (rainbow trout embryo), RTT (rainbow trout tail), and SEH ("sake" or chum salmon embryo head). Nonsalmonid cell lines derived from pond smelt Hуроmesus olidus, chevron snakehead Channa striata, and goldfish Carassius auratus were designated WF-1 ("wakasagi" fin), SHH (snakehead heart), and EPG (epithelioma papulosum of goldfish), respectively. Optimum growth for most of the cell lines was observed in Eagle's minimum essential medium buffered with sodium bicarbonate $(26 \mathrm{mM})$ or a combination of sodium bicarbonate $(8.9$ $\mathrm{mM})$ and tris $(16 \mathrm{mM})$. Likewise, most of the cell lines showed optimum growth at the lowest $\mathrm{NaCl}$ concentration tested $(0.116 \mathrm{M})$. Optimum growth temperatures ranged from 15 to $20^{\circ} \mathrm{C}$ for the salmonid cell lines and from 15 to $30^{\circ} \mathrm{C}$ for nonsalmonid cell lines. Except for RTT, the cell lines were heteroploid. Eleven fish viruses were used to test the susceptibility of these cell lines. Cell lines derived from salmonids developed cytopathic effects (CPE) when infected with 10 of the 11 fish viruses tested, except for RTT, which produced CPE with only 8 of the fish viruses. Six fish rhabdoviruses used in this study elicited a pronounced CPE when inoculated into nonsalmonid cell lines EPG, WF-1, and SHH. Among the new cell lines, RTE-2 showed the best potential for the isolation of fish viruses.
\end{abstract}

Fishes are the largest and most diverse group of vertebrates, constituting $48 \%$ of the species in the phylum Vertebrata (Wolf and Mann 1980; Bols and Lee 1991). Techniques used in the development of fish cell lines were initiated through the earlier works of Fryer et al. (1965) and Wolf and Quimby (1976a, 1976b, 1976c). Subsequently, culture of cells and tissues of teleosts rapidly progressed and the first comprehensive listing of poikilotherm vertebrate cell lines was published by Wolf and Mann (1980).

In addition to being an invaluable tool for understanding problems related to fish health, fish cell lines have had application in biomedical research (Hightower and Renfro 1988), toxicology (Babich and Borenfreund 1991), fundamental fish research (Nicholson 1988), and research in antiviral drugs and chemicals (Kimura et al. 1989; Kamei et al. 1992). Recent reviews include an update of fish cell culture methods (Nicholson 1989) and reports of the role and uses of cell cultures from fish, shellfish, and seaweeds in biotechnology and aquaculture (Bols 1991; Bols and Lee 1991). These reviews have provided additional information on the potential roles of fish cell lines in science and technology, suggesting that there is a continuing need to develop and establish new cell lines from aquatic organisms.

This article describes the establishment and characterization of seven continuous cell lines from the embryo, tail, fin, heart, and an abnormal tissue of five species of salmonid and nonsalmonid fish.

\section{Methods}

\section{Primary Cultures}

Of the salmonid cell lines, RTE and RTE-2 (rainbow trout embryo) were derived from pooled eyed embryos of rainbow trout Oncorhynchus mykiss, RTT (rainbow trout tail) was derived from the tail muscle of the same species, and SEH ("sake" embryo head) was derived from pooled eyed embryos of chum salmon $O$. keta. Of the nonsalmonid cell lines, EPG (epithelioma papulosum of goldfish) was derived from an abnormal tissue of goldfish Carassius auratus, WF-1 ("wakasagi" fin) was derived from the fin of a pond smelt Hypomesus olidus, and SHH (snakehead heart) was derived from the heart tissue of chevron snakehead Channa striata (Table 1).

The RTE and RTT cell lines were donated by B. J. Hill, Fish Disease Laboratory, Weymouth, UK, and had been initiated from cells obtained after trypsin digestion of minced tissues (Wolf and Quimby 1976c). The other cell lines were initiated in our laboratory according to methods similar to those described by Wolf and Quimby (1976a) and Lannan et al. (1984). 
TABLE 1.-Origin and morphology of the new cell lines from freshwater fish.

\begin{tabular}{llll}
\hline $\begin{array}{l}\text { Cell } \\
\text { line }\end{array}$ & \multicolumn{1}{c}{ Species } & $\begin{array}{c}\text { Tissue of } \\
\text { origin }\end{array}$ & Morphology \\
\hline RTE & Rainbow trout & Embryo & Epithelioid \\
RTE-2 & Rainbow trout & Embryo & Epithelioid \\
RTT & Rainbow trout & Tail & Fibroblastic \\
SEH & Chum salmon & Embryo & Epithelioid \\
EPG & Goldfish & Epithelioma & Epithelioid \\
WF-1 & Pond smelt & Fin & Epithelioid \\
SHH & Chevron snakehead & Heart & Epithelioid \\
\hline & & &
\end{tabular}

\section{Conditions for Cell Growth}

The effects of various culture media, temperatures, and $\mathrm{NaCl}$ concentrations on the growth of these cells were examined. Three standard cell culture media were tested: Eagle's minimum essential medium (Eagle's MEM, GIBCO), Leibovitz's L-15 medium (GIBCO), and medium 199 (GIBCO). In Eagle's MEM, three buffer systems were used: sodium bicarbonate alone $(26 \mathrm{mM})$; sodium bicarbonate $(8.9 \mathrm{mM})$ with tris $(16 \mathrm{mM})$; and sodium bicarbonate $(8.9 \mathrm{mM})$ with HEPES $(14 \mathrm{mM})$. All media were supplemented with $10 \%$ fetal bovine serum (FBS) and antibiotics from Sigma (100 IU penicillin and $100 \mu \mathrm{g}$ streptomycin per milliliter). Growth of all cell lines was tested at 10, 15, 20, 25 , and $30^{\circ} \mathrm{C}$; the EPG, WF-1, and $\mathrm{SHH}$ cell lines were also incubated at 35 and $40^{\circ} \mathrm{C}$. During the determination of optimum growth temperature, the culture medium giving the highest growth response for each cell line was used.

To determine the $\mathrm{NaCl}$ requirement of the cells, Eagle's MEM buffered with a combination of sodium bicarbonate $(8.9 \mathrm{mM})$ and tris $(16 \mathrm{mM})$ was supplemented with $\mathrm{NaCl}$ to provide final $\mathrm{NaCl}$ concentrations of $0.171,0.256,0.341$, and 0.512 M. A stock solution of Eagle's MEM containing an $\mathrm{NaCl}$ concentration of $3.40 \mathrm{M}$ was used to adjust the above test concentrations. The $\mathrm{NaCl}$ concentration of the commercial medium $(0.116 \mathrm{M})$ was used as a control.

For all of the above tests, cells were inoculated into 48 wells of a 96-well microplate at initial concentrations ranging from $1 \times 10^{5}$ to $2 \times 10^{5}$ cells $/ \mathrm{mL}$ and their growth was observed for $7 \mathrm{~d}$. Cell growth was measured after 1 and $7 \mathrm{~d}$ by the absorbance method of Fernandez et al. (1993, this issue). Cells were fixed with $10 \%$ formalin for 30 $60 \mathrm{~min}$ then rinsed with tap water. Washed cells were stained with $0.1 \%$ crystal violet for $1-2 \mathrm{~h}$, washed again, and allowed to air-dry in the microplates. Absorbance of stained cells in the microplates was read with a microplate spectrophotometer (Corona MTP-22) at $600 \mathrm{~nm}$.
Ánalysis of variance was employed in statistical evaluation of data at significance levels of $P \leq$ 0.01 and $P \leq 0.05$. Comparison of means was based on Duncan's new multiple-range test (Wakimoto et al. 1984).

\section{Chromosome Counts and Efficiency of Plating}

Preparation and fixation of the cells for chromosome analysis was performed according to the methods described by Earley (1975).

Efficiency of plating was determined by the method of Fryer et al. (1981). The ability of both salmonid and nonsalmonid cells to form colonies was determined after plating at low densities $\left(10^{2}\right.$ and $10^{3}$ cells $/ \mathrm{mL}$ ) and $20 \mathrm{~d}$ of incubation. An established cell line, chum salmon heart (CHH-1, Lannan et al. 1984), was used as a control.

\section{Cytopathic Effects and Viral Replication}

Cytopathic effect (CPE) and viral replication in the new cell lines were determined after inoculation of 11 fish viruses (Table 2). Stocks of the viruses were prepared in the following cell lines: chinook salmon embryo (CHSE-214; Lannan et al. 1984), epithelioma papulosum cyprini (EPC; Fijan et al. 1983), rainbow trout gonad (RTG-2; Wolf and Quimby 1962), and channel catfish ovary (CCO; Bowser and Plumb 1980a). Cells were seeded at a density of $10^{5}$ cells/well in a 24-well microplate and incubated for $24 \mathrm{~h}$ before the virus was inoculated. Each virus was inoculated at a multiplicity of infection of 0.1 into two wells for each of the cell lines. Cell lines inoculated with $H$. salmonis were incubated at $10^{\circ} \mathrm{C}$, those with $\mathrm{CCV}$ were incubated at $20^{\circ} \mathrm{C}$, and cell lines with any of the other viruses were incubated at $15^{\circ} \mathrm{C}$. The cells were observed for at least 2 weeks for CPE.

Cell lines showing CPE for IPNV VR299, IHNV $\mathrm{ChAb}, \mathrm{HRV}, \mathrm{CSV}$, OMV, or H. salmonis were further tested for virus replication efficiency. Cells of each line to be tested were seeded in $25-\mathrm{cm}^{2}$ tissue culture flasks (Falcon) and incubated for 3 $\mathrm{d}$ before virus inoculation. Stocks of each virus were inoculated at a multiplicity of infection of 0.01 onto duplicate monolayers. To allow absorption of the virus, the flasks were incubated in a vertical position at $15^{\circ} \mathrm{C}$ for $1 \mathrm{~h}$, after which the flasks were laid flat for normal incubation. Subsequently, all inoculated cultures were incubated at $15^{\circ} \mathrm{C}$, except for those inoculated with $H$. salmonis, which were incubated at $10^{\circ} \mathrm{C}$, and those inoculated with $\mathrm{CCV}$, which were incubated at $20^{\circ} \mathrm{C}$. Titers of each virus-cell line combination were determined by pooling $100 \mu \mathrm{L}$ from each duplicate flask and assaying for $50 \%$ tissue culture 
TABLE 2.-Fish viruses used for the production of cytopathic effect in the new freshwater fish cell lines.

\begin{tabular}{|c|c|c|}
\hline Virus & $\begin{array}{c}\text { Acronym } \\
\text { (and virus type) }\end{array}$ & Source (or original reference) ${ }^{a}$ \\
\hline Channel catfish virus & $\mathrm{CCV}$ & J. A. Plumb, Auburn University, Alabama \\
\hline Chum salmon virus & CSV & Winton et al. (1981) \\
\hline Eel virus of America & EVA & T. Sano, Tokyo University of Fisheries, Tokyo \\
\hline Eel virus of Europe $X$ & EVEX & T. Sano \\
\hline Herpesvirus salmonis & H. salmonis & $\begin{array}{l}\text { K. Wolf, National Fish Health Research } \\
\text { Laboratory, Kearneysville, West Virginia }\end{array}$ \\
\hline Hirame rhabdovirus & HRV & Kimura et al. (1986) \\
\hline Infectious hematopoietic necrosis virus & IHNV NAV & $\begin{array}{l}\text { J. R. Winton, National Fisheries Research Center, } \\
\text { Seattle, Washington }\end{array}$ \\
\hline & IHNV ChAb & Yoshimizu et al. (1989) \\
\hline Infectious pancreatic necrosis virus & IPNV VR299 & K. Wolf \\
\hline Oncorhynchus masou virus & OMV & Kimura et al. (1981) \\
\hline Pike fry rhabdovirus & PFRV & $\begin{array}{l}\text { B. J. Hill, Fish Disease Laboratory, } \\
\text { Weymouth, UK }\end{array}$ \\
\hline Spring viremia of carp virus & SVCV & B. J. Hill \\
\hline
\end{tabular}

a If the author of the original reference was also the source, the reference is noted.

infective dose (TCID50/mL; Reed and Muench 1938).

\section{Results}

\section{Cell Morphology}

The established cell lines from nonsalmonid fish were clearly epithelioid, whereas the RTT cell line was fibroblastic. Other salmonid cell lines were intermediate, appearing mostly epitheliallike (Table 1; Figure 1).

\section{Conditions for Cell Growth}

Growth of the cell lines derived from salmonid and nonsalmonid fish was evaluated under various physiological conditions. Seven days after inoculation, absorbance readings of the seven cell lines grown in microplate wells containing Eagle's MEM buffered with sodium bicarbonate alone or Eagle's MEM buffered with a combination of sodium bicarbonate and tris were significantly higher $(P \leq 0.05)$ than those of cell lines grown in other culture media (Figure 2).

Optimum growth temperature was higher for the nonsalmonid cell lines, except the EPG cell line, ranging from 20 to $25^{\circ} \mathrm{C}$ for SHH cells and from 20 to $30^{\circ} \mathrm{C}$ for WF-1 cells. Optimum growth temperature for EPG cells was $15-20^{\circ} \mathrm{C}$. For the salmonid cell lines RTE, RTE-2, and RTT, optimum growth temperature was $20^{\circ} \mathrm{C}$ and little growth occurred at $25^{\circ} \mathrm{C}$. For SEH cells, optimum growth temperature was $15-20^{\circ} \mathrm{C}$. No cell lines from salmonid fish showed growth at $30^{\circ} \mathrm{C}$. Among the nonsalmonid cell lines, WF-1 showed tolerance for the highest temperature (up to $35^{\circ} \mathrm{C}$ ), but none of these cells were able to grow at $40^{\circ} \mathrm{C}$ (Figure 3).

Both salmonid and nonsalmonid cell lines, except for RTE, adapted to the lowest $\mathrm{NaCl}$ concentration of $0.116 \mathrm{M}$ in the medium. Growth responses of most cell lines were inversely proportional to the $\mathrm{NaCl}$ concentration in the medium (Figure 4).

\section{Chromosome Counts and Efficiency of Plating}

Six of the seven cell lines were heteroploid and consisted of $1 \mathrm{n}$ or $3 \mathrm{n}$ cells. The RTE cell line developed a bimodal chromosome distribution with peaks at 51 and 90 and a range of chromosomes from 40 to 94 (Figure 5). Conversely, only one peak was observed for the RTE-2 cell line, which had a modal chromosome number of 90 . At passage 79, the modal chromosome number for RTT was 60 , and the chromosome number ranged from 50 to 114 . The diploid number mostly reported for rainbow trout is from 53 to 63 (Ojima 1983). However, Ojima (1983) also reported diploid numbers of 89 and 90 for rainbow trout. Chum salmon has a diploid number of 74 , but its cell line, SEH, had a modal chromosome number of 46 and chromosome counts that ranged from 40 to 54. The same modal chromosome number (49) was determined for the nonsalmonid cell lines EPG and WF-1; however, the diploid number is 100 for goldfish and 56 for pond smelt. The SHH cell line had a broad range of chromosome counts, from 21 to 118 .

Except for RTT, six of the seven cell lines showed relatively high plating efficiencies, comparable to those of the control cell line, $\mathrm{CHH}-1$ 

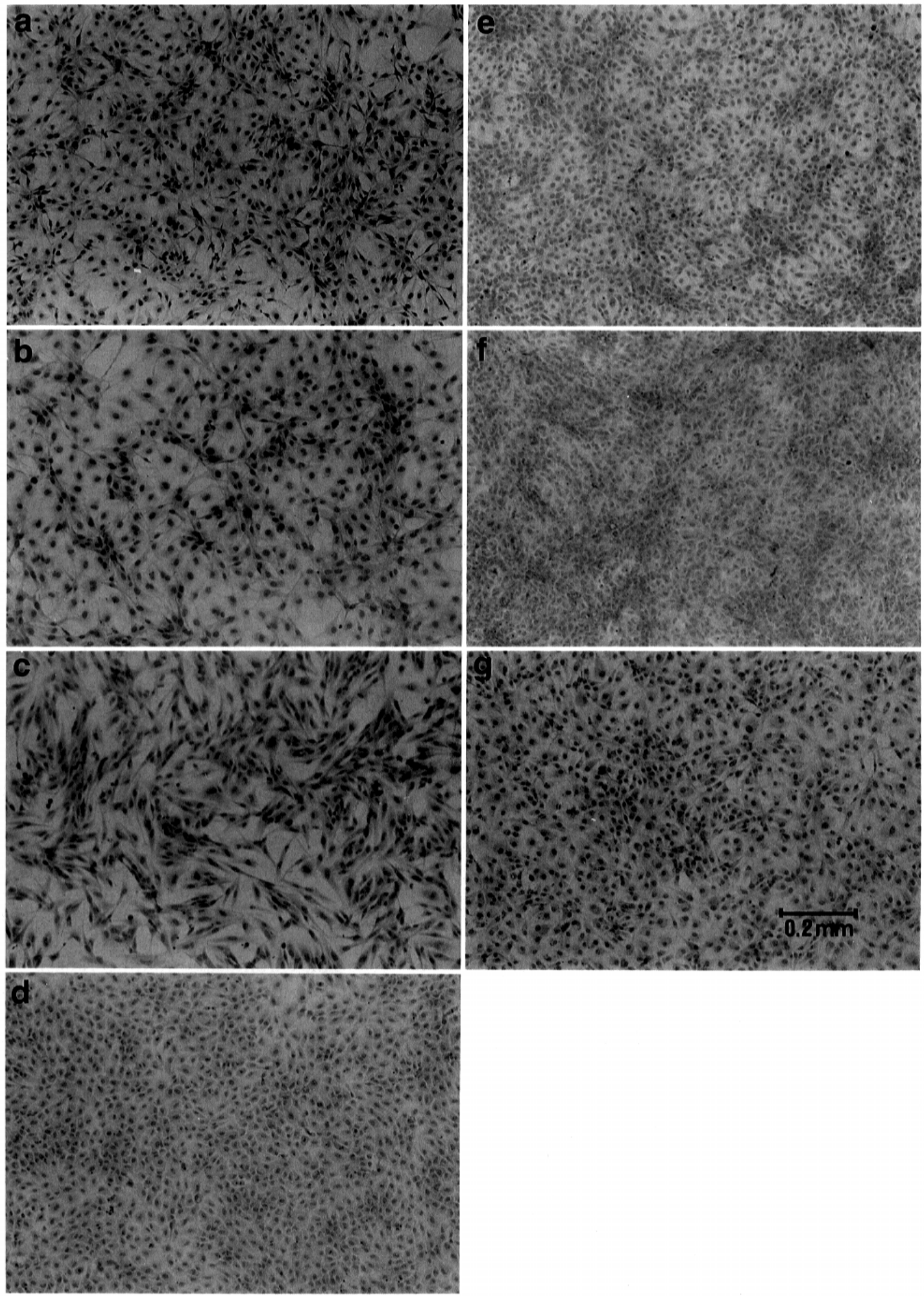

FIGURE 1.-Monolayers of new cell lines from freshwater fish: (a ) RTE; (b ) RTE-2; (c) RTT; (d) SEH; (e ) EPG; (f) WF-1; and (g) SHH. 

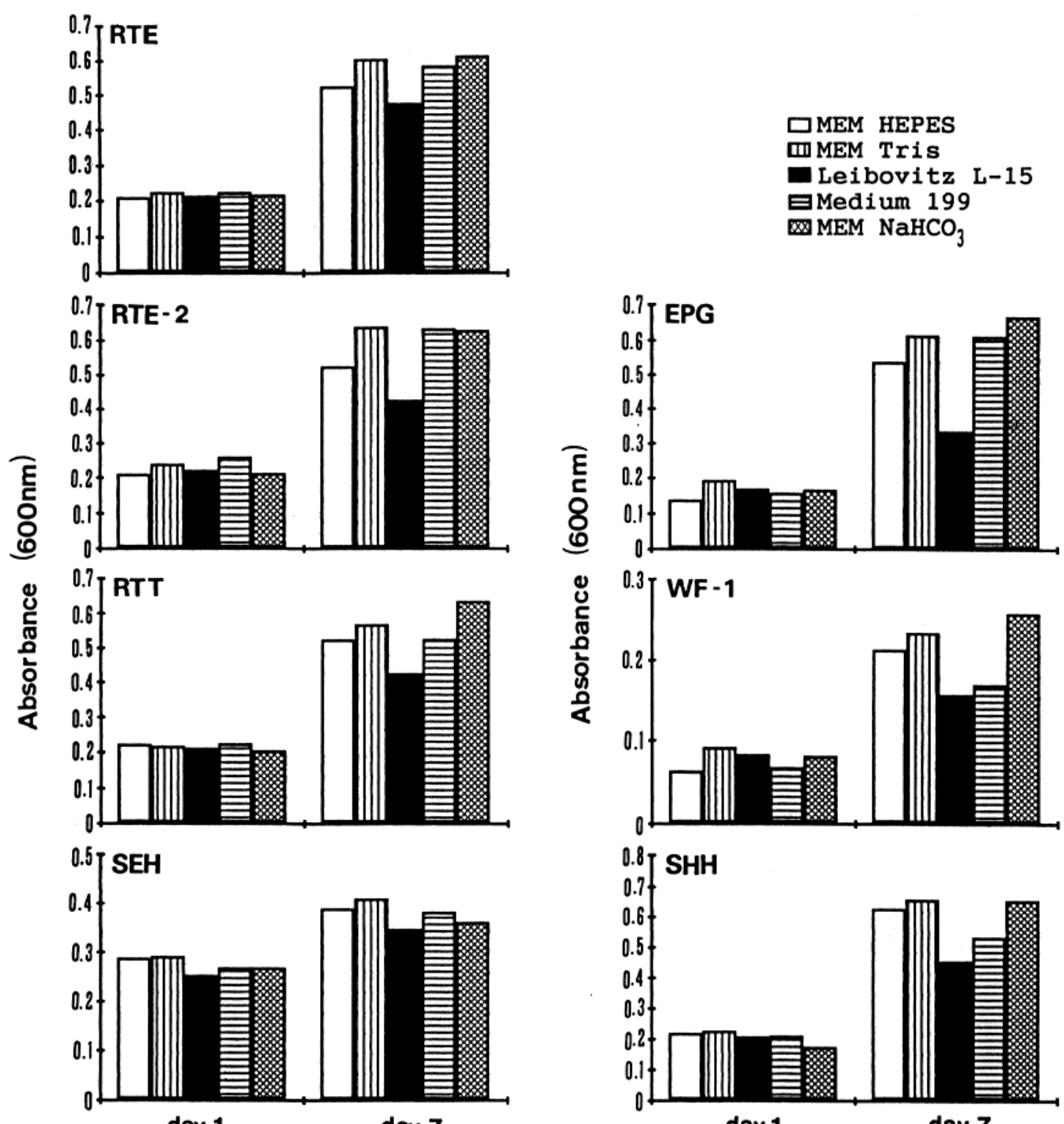

day 1

day 7

Incubation period (days)

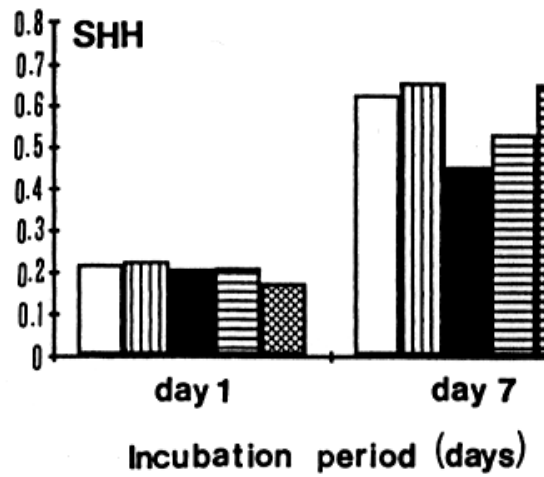

FIGURE 2.-Growth of (left) salmonid and (right) nonsalmonid cell lines in selected culture media. The buffer systems with Eagle's minimum essential medium with Earle's salts (MEM) are abbreviated here as follows: MEM HEPES = MEM with sodium bicarbonate and HEPES; MEM Tris = MEM with sodium bicarbonate and tris; and MEM NaHCO $\mathrm{N}_{3}=$ MEM with sodium bicarbonate alone.

(Table 3). The RTT cell line showed the lowest plating efficiencies (3.0 and 3.8\%).

\section{Cytopathic Effects and Viral Replicability}

Cell lines derived from salmonids developed CPE with 10 of the 11 fish viruses, except for RTT cells, which did not show CPE for $H$. salmonis or
CSV. Also, CPE was not observed in SEH cell line inoculated with IPNV VR299. All salmonid cell lines were refractory to CCV (Table 4). Nonsalmonid cell lines EPG and WF-1 were refractory to IPNV, OMV, CCV, and CSV; and of the three nonsalmonid cell lines, only WF-1 showed CPE for $H$. salmonis. The SHH cell line showed CPE 

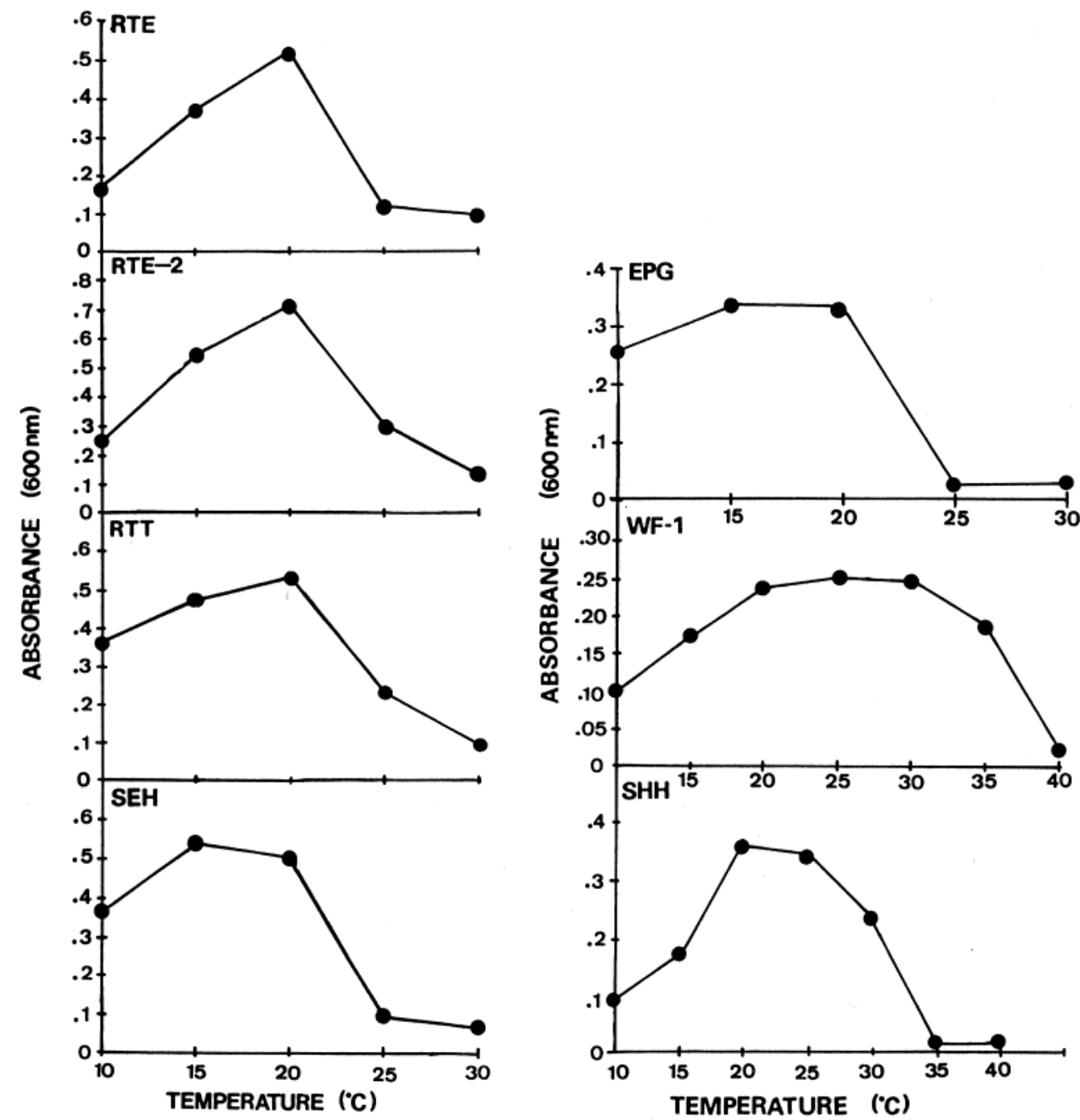

FIGURE 3.-Growth responses of (left ) salmonid and (right) nonsalmonid cell lines at various temperatures.

for seven of the viruses; no CPE was observed for H. salmonis, CCV, and CSV. On the other hand, pronounced CPE was observed in nonsalmonid cell lines challenged with six fish rhabdoviruses.

Yields of IPNV VR299, IHNV ChAb, HRV, $\mathrm{OMV}, H$. salmonis, and CSV were determined. High titers of IPNV were observed in RTE, RTE2, and SHH cell lines (Figure 6). For IHNV, salmonid line RTE-2 and nonsalmonid line EPG showed high yield of the virus. High viral titer for HRV was attained in cell lines RTE-2, EPG, WF1, and SHH cell lines. For $H$. salmonis, moderate but increasing titers were observed in RTE and RTE-2 cells. Titers of OMV were low and the virus was detected only on day 15 , except in RTE cell line. In RTE cell line, titer of OMV was mod- erately high with increasing yield until day 26 . The RTE cells initially showed CPE for CSV but the virus failed to replicate in these cells and, among the new cell lines, only RTE- 2 and SEH allowed replication of the virus. The cell lines RTE or RTE-2 produced consistently high to moderate titers of almost all viruses. In some cell lines, titers of IPNV, IHNV, and HRV were highest 1 week after inoculation.

\section{Discussion}

We have established and observed the characteristics of seven cell lines from normal embryo, tail, embryo head, fin, or heart tissues of salmonid and nonsalmonid fish and from an abnormal tissue of goldfish. As described here and in our pre- 

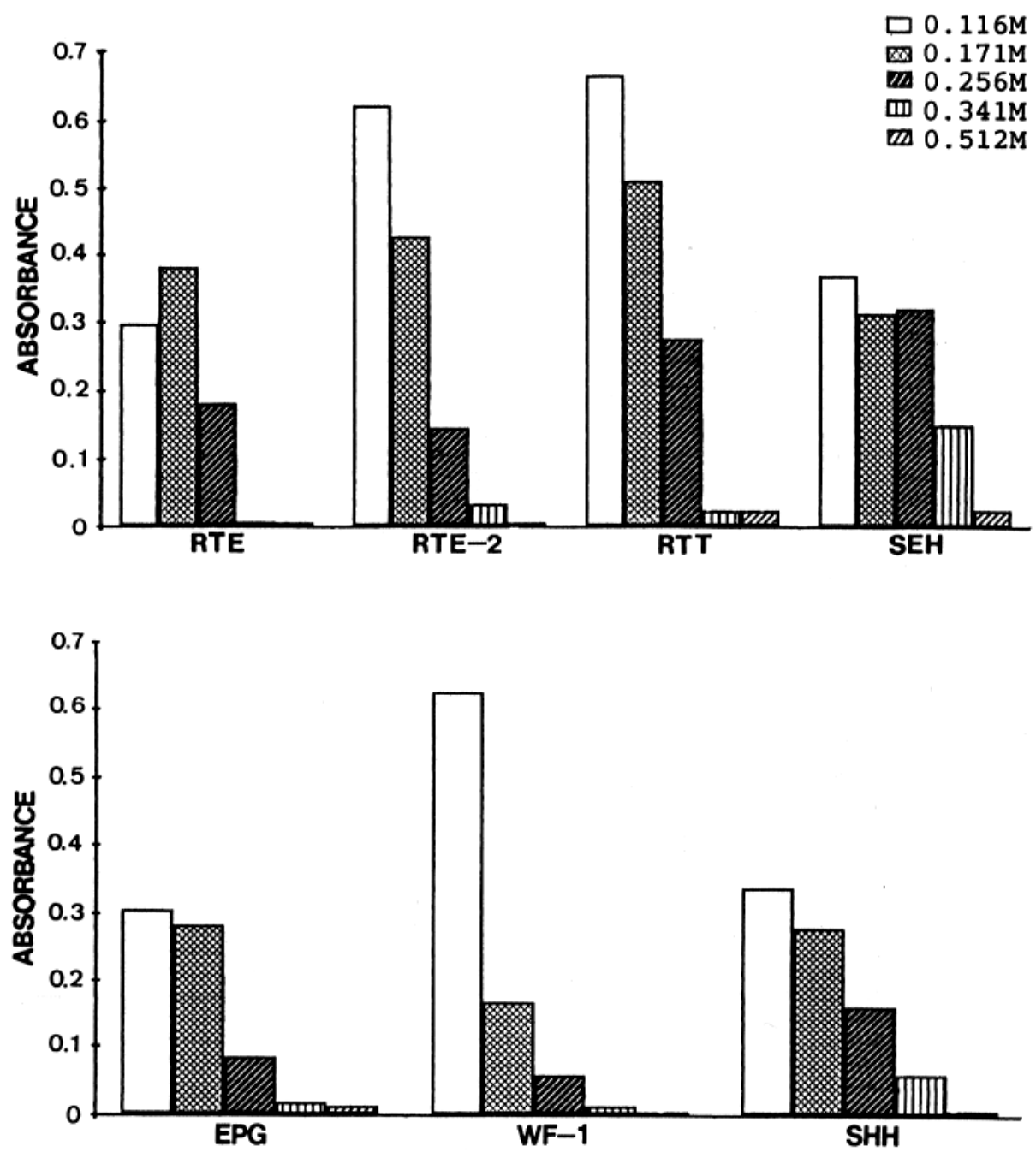

FIGURE 4.-Growth responses of (top ) salmonid and (bottom ) nonsalmonid cell lines at various $\mathrm{NaCl}$ molarities.

vious report (Fernandez et al. 1993), we used a staining and absorbance method to determine growth responses of the cells. In this method, although both dead and live cells were stained, increase in absorbance indicated cell proliferation.

One of the earliest reports on the in vitro cultivation of trout and salmonid cells was that of Fryer et al. (1965). Of the two media used in their study, Eagle's basal medium and Eagle's MEM, the latter was superior and produced significant improvements in growth. We have shown that Eagle's MEM alone or buffered with a combination of sodium bicarbonate and tris allowed substantial growth of both salmonid and nonsalmonid cells. These results are similar to those obtained in the establishment of cell lines from marine fish (Fer- nandez et al. 1993). In contrast, Leibovitz's L-15 medium is frequently used by fish tissue culturists in the establishment of fish cell lines from warmwater fish. Although medium 199 was the first culture medium used for fish tissue culture (Wolf and Quimby 1969), it is now used less frequently.

In vitro, fish cells grow over a wider range of temperatures than do cell cultures from homeothermic animals (Wolf and Mann 1980; Bols and Lee 1991). Cell cultures obtained from coldwater fishes usually have optimum growth at a temperature range of $15-20^{\circ} \mathrm{C}$; cell cultures from intermediate or coolwater fishes have a lethal limit at a higher temperature and show optimum growth between 20 and $28^{\circ} \mathrm{C}$; and warmwater fish cell cultures have optimum growth at temperatures 


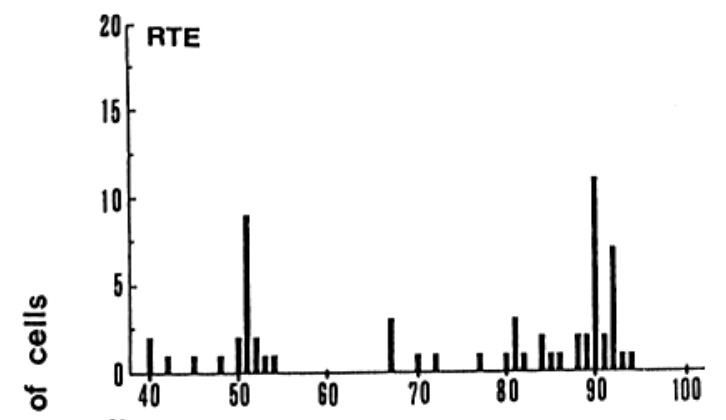

है
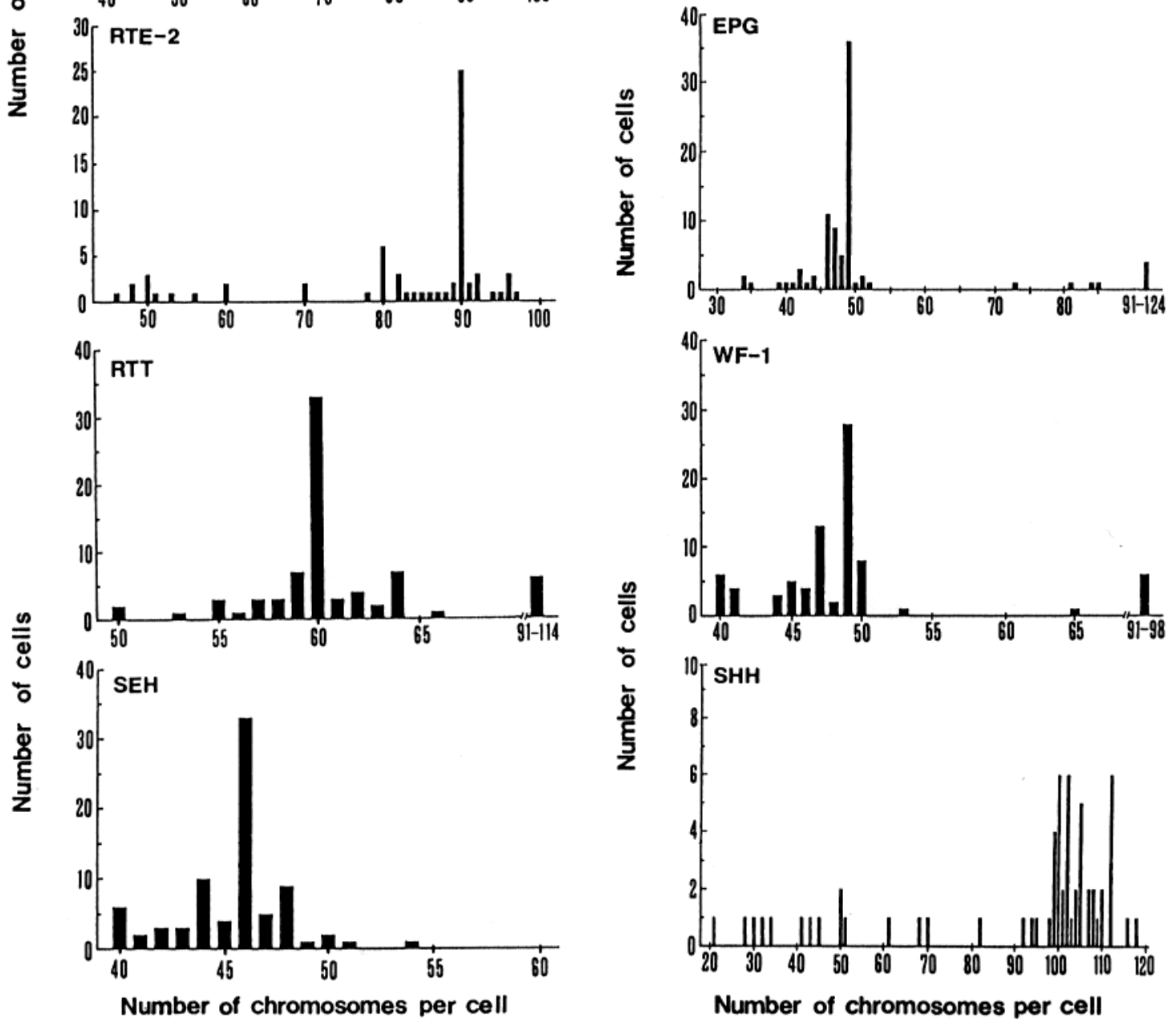

FIGURE 5.-Frequency distributions of chromosomes from (left) salmonid and (right) nonsalmonid cell lines.

between 25 and $37^{\circ} \mathrm{C}$ (Nicholson 1988). Our results confirm that the optimum growth temperature for a fish cell culture is a reflection of the optimum growth temperature for the host in its natural environment. The $25^{\circ} \mathrm{C}$ inhibitory limit for coldwater species (Wolf and Mann 1980) was also observed in our study.

The diploid chromosome number of rainbow trout is reported to vaiy usually from 58 to 60 , although $2 \mathrm{n}$ in some individuals has been reported to be 89 or 90 (Ojima 1983). The RTE cell line exhibited bimodal chromosome numbers of 51 and 90, whereas RTE-2 had a modal number of 90. Yoshimizu et al. (1988) reported 54 as the modal chromosome number for the RTE cell line at passage 38 . This shift in the chromosome count 
TABLE 3.-Plating efficiencies for the new cell lines from freshwater fish; $\mathrm{CHH}-1$ was the control cell line.

\begin{tabular}{lccc}
\hline Cell line & $\begin{array}{c}\text { Cells seeded/ } \\
25-\text { cm }^{2} \text { flask }\end{array}$ & $\begin{array}{c}\text { Average number } \\
\text { of cell colonies }\end{array}$ & $\begin{array}{c}\text { Efficiency of } \\
\text { plating }(\%)^{\mathrm{a}}\end{array}$ \\
\hline RTE-2 & $10^{3}$ & 327 & 32.7 \\
& $10^{2}$ & 46 & 46.0 \\
RTT & $10^{3}$ & 38 & 3.8 \\
& $10^{2}$ & 3 & 3.0 \\
SEH & $10^{3}$ & 228 & 22.8 \\
& $10^{2}$ & 27 & 27.0 \\
EPG & $10^{3}$ & 324 & 32.4 \\
& $10^{2}$ & 48 & 48.0 \\
WF-1 & $10^{3}$ & 241 & 24.1 \\
& $10^{2}$ & 35 & 35.0 \\
SHH & $10^{3}$ & TNTC & \\
& $10^{2}$ & 41 & 41.0 \\
CHH-1 & $10^{3}$ & 344 & 34.4 \\
& $10^{2}$ & 37 & 37.0
\end{tabular}

a (Number of cell colonies/cells seeded) $\times 100$.

b TNTC $=$ too numerous to count.

was perhaps due to repeated passage. Wolf and Quimby (1969) reported that, of the fish cell lines for which chromosome numbers had been determined, all were heteroploid, and that attainment
TABLE 4.-Cytopathic effect produced in new freshwater fish cell lines after infection with 11 fish viruses. Virus acronyms are as defined in Table 2.

\begin{tabular}{|c|c|c|c|c|c|c|c|}
\hline \multirow[b]{2}{*}{ Virus } & \multicolumn{4}{|c|}{$\begin{array}{l}\text { Salmonid } \\
\text { cell lines }\end{array}$} & \multicolumn{3}{|c|}{$\begin{array}{l}\text { Nonsalmonid } \\
\text { cell lines }\end{array}$} \\
\hline & RTE & RTE-2 & RTT & SEH & EPG & WF-1 & SHH \\
\hline IPNV Ab & + & + & + & + & - & - & + \\
\hline IPNV VR299 & + & + & + & - & - & - & + \\
\hline IHNV NAV & + & + & + & + & + & + & + \\
\hline IHNV ChAb & + & + & + & + & + & + & + \\
\hline HRV & + & + & + & + & + & + & + \\
\hline SVCV & + & + & + & + & + & + & + \\
\hline EVA & + & + & + & + & + & + & + \\
\hline EVEX & + & + & + & + & + & + & + \\
\hline PFRV & + & + & + & + & + & + & + \\
\hline OMV & + & + & + & + & - & - & $n t^{a}$ \\
\hline H. salmonis & + & + & - & + & - & + & - \\
\hline $\mathrm{CCV}$ & - & - & - & - & - & - & - \\
\hline CSV & + & + & - & + & - & - & - \\
\hline
\end{tabular}

a $\mathrm{nt}=$ not tested.

of the potential for indefinite subculturing among all animal cell lines is usually accompanied by alteration to a heteroploid chromosome constitution. The relatively high plating efficiency values
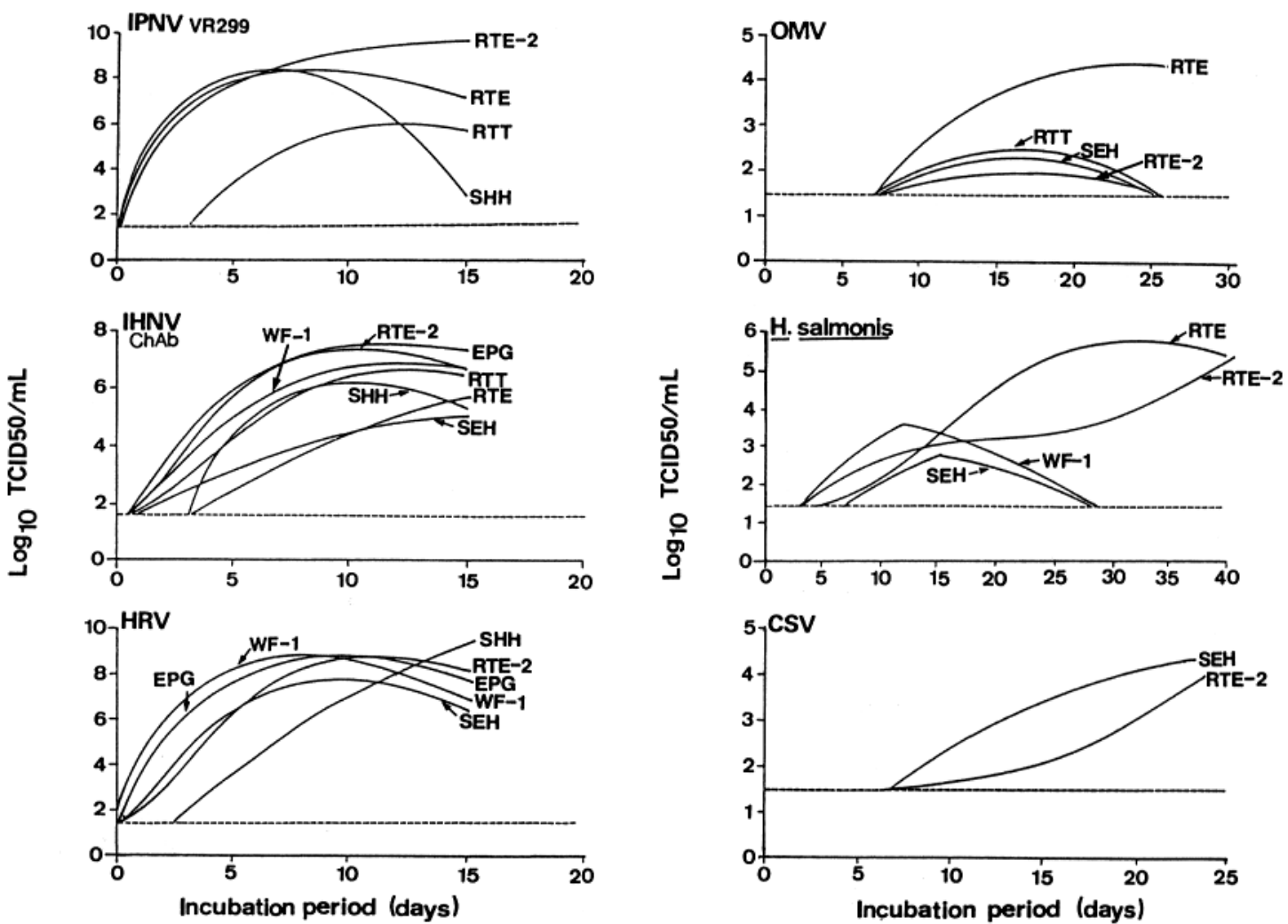

FiguRE 6.-Titers for six fish viruses incubated in newly established salmonid and nonsalmonid cell lines. Virus acronyms are defined in Table 2 . Within each graph, the horizontal line denotes the threshold line for detection (virus titer of at least 1.5). 
obtained for six of the cell lines in the present study indicate that these cells are transformed and can be considered as established lines.

Providing additional fish cell lines will increase the number of laboratory tools available to fish virologists and pathologists. The four new cell lines from salmonid fish showed susceptibility to almost all fish viruses tested, except CCV, and provided high yields of IPNV VR299, IHNV ChAb, and HRV a week after infection, even when the initial inoculum dose was very low. Although CCV is known to be a highly cell-specific virus that replicates only in ictalurid cell lines (Bowser and Plumb 1980b; Wolf 1988), it has been found to replicate in some marine fish cell lines (Fernandez et al. 1993). Among the cell lines, RTE-2 produced consistently high yields for all viruses except OMV. These results suggested that, along with other well-known fish cell lines routinely used for viral isolation, such as CHSE-214 (Lannan et al. 1984) and RTG-2 (Wolf and Quimby 1962), the RTE- 2 cell line may prove useful for isolation and production of some fish viruses.

In this article, we have reported the establishment of additional continuous fish cell lines having a good potential for detecting fish viruses, including those that still await isolation. These lines are available to any interested worker.

\section{Acknowledgments}

We are grateful to B. J. Hill for his additional cell lines and for reviewing this manuscript. This study was supported by a grant under the Ministry of Education, Culture and Science of Japan, International Scientific Research Program 02044008.

\section{References}

Babich, H., and E. Borenfreund. 1991. Cytotoxicity and genotoxicity assays with cultured fish cells: a review. Toxicology In Vitro 5:91-100.

Bols, N. C. 1991. Biotechnology and aquaculture: the role of cell cultures. Biotechnology Advances 9:3149.

Bols, N. C., and L. E. J. Lee. 1991. Technology and uses of cell cultures from the tissues and organs of bony fishes. Cytotechnology 6:163-187.

Bowser, P. R., and J. A. Plumb. 1980a. Fish cell lines: establishment of a line from ovaries of channel catfish. In Vitro (Rockville) 16:365-368.

Bowser, P. R., and J. A. Plumb. 1980b. Growth rates of a new cell line from channel catfish ovary and channel catfish virus replication at different temperatures. Canadian Journal of Fisheries and Aquatic Sciences 37:871-873.

Earley, E. M. 1975. Chromosome preparations from monolayer cell cultures. Tissue Culture Association Manual 1:31-35.

Fernandez, R. D., M. Yoshimizu, T. Kimura, Y. Ezura, K. Inouye, and I. Takami. 1993. Characterization of three continuous cell lines from marine fish. Journal of Aquatic Animal Health 5:127-136.

Fijan, N., and seven coauthors. 1983. Some properties of the epithelioma papulosum cyprini (EPC) cell line from carp Cyprinus carpio. Annales de Virologie (Paris) 134E:207-220.

Fryer, J. L., B. B. McCain, and J. C. Leong. 1981. A cell line derived from rainbow trout (Salmo gairdneri) hepatoma. Fish Pathology 15:193-200.

Fryer, J. L., A. Yusha, and S. Pilcher. 1965. The in vitro cultivation of tissues and cells of Pacific salmon and steelhead trout. Annals of the New York Academy of Sciences 126:566-586.

Hightower, L. E., and J. L. Renfro. 1988. Recent applications of fish cell culture to biomedical research. Journal of Experimental Zoology 248:290-302.

Kamei, Y., M. Yoshimizu, Y. Ezura, and T. Kimura. 1992. Isolation and characterization of antiviral substance against salmonid viruses, 46NW-04A produced by an aquatic bacterium, Pseudomonas fluorescens 46NW-04. Pages 293-300 in T. Kimura, editor. Salmonid diseases. Hokkaido University Press, Sapporo, Japan.

Kimura, T., M. Yoshimizu, Y. Ezura, and Y. Kamei. 1989. Interaction between fish pathogenic viruses and microorganisms in environmental water of fish. Pages 587-591 in T. Hattori, Y. Ishida, Y. Maruyama, R. Morita, and A. Uchida, editors. Recent advances in microbial ecology. Japan Scientific Societies Press, Tokyo.

Kimura, T., M. Yoshimizu, and S. Gorie. 1986. A new rhabdovirus isolated in Japan from cultured hirame (Japanese flounder) Paralichthys olivaceus and ayu (Plecoglossus altivelis). Diseases of Aquatic Organisms 1:207-217.

Kimura, T., M. Yoshimizu, M. Tanaka, and H. Sannohe. 1981. Studies on a new virus (OMV) from Oncorhynchus masou. I. Characteristics and pathogenicity. Fish Pathology 15:143-147.

Lannan, C. N., J. R. Winton, and J. L. Fryer. 1984. Fish cell lines: establishment and characterization. In Vitro (Rockville) 20:671-676.

Nicholson, B. L. 1988. Fish cell cultures: an overview. Pages 191-194 in Y. Kuroda, E. Kurstak, and K. Maramorosch, editors. Invertebrate and fish tissue culture. Japan Scientific Societies Press, Tokyo. (Also: Springer-Verlag, Berlin.)

Nicholson, B. L. 1989. Fish cell culture: an update. Advances in Cell Culture 7:1-18.

Ojima, Y. 1983. [Fish cytogenetics.] Suikousha, Tokyo. (In Japanese.)

Reed, J. L., and H. A. Muench. 1938. A simple method of estimating fifty percent end points. American Journal of Hygiene 27:493-497.

Wakimoto, K., T. Tarumi, and Y. Tanaka. 1984. [Personal computer handbook: statistical analysis. I. Basic statistics.] Kyouritsu Press, Tokyo. (In Japanese.) 
Winton, J. R., C. N. Lannan, J. L. Fryer, and T. Kimura. 1981. Isolation of a new reovirus from chum salmon. Fish Pathology 15:155-162.

Wolf, K. 1988. Fish viruses and fish viral diseases. Cornell University Press, Ithaca, New York.

Wolf, K., and J. A. Mann. 1980. Poikilotherm vertebrate cell lines and viruses: a current listing for fishes. In Vitro (Rockville) 16:168-179.

Wolf, K., and M. C. Quimby. 1962. Established eurythermic line of fish cells in vitro. Science (Washington, D.C.) 135:1065-1066.

Wolf, K., and M. C. Quimby. 1969. Fish cell and tissue culture. Pages 253-303 in W. S. Hoar and D. J. Randall, editors. Fish physiology, volume 3. Academic Press, New York.

Wolf, K., and M. C. Quimby. 1976a. Primary monolayer culture of fish cells initiated from minced tissues. Tissue Culture Association Manual 2:445-448.

Wolf, K., and M. C. Quimby. 1976b. Procedures for subculturing fish cells and propagating fish cell lines. Tissue Culture Association Manual 2:471-474.

Wolf, K., and M. C. Quimby. 1976c. Primary monolayer culture of fish cells initiated from trypsinized tissue. Tissue Culture Association Manual 2:453457.

Yoshimizu, M., M. Kamei, S. Dirakbusarakom, and T. Kimura. 1988. Fish cell lines: susceptibility to salmonid viruses. Pages 207-210 in Y. Kuroda, E. Kurstak, and K. Maramorosch, editors. Invertebrate and fish tissue culture. Japan Scientific Societies Press, Tokyo. (Also: Springer-Verlag, Berlin.)

Yoshimizu, M., T. Nomura, T. Awakura, Y. Ezura, and T. Kimura. 1989. Prevalence of pathogenic fish viruses in anadromous masu salmon (Oncorhynchus masou) in the northern part of Japan, 19761987. Physiology and Ecology Japan (Special Volume) 1:559-576. 